\title{
Bimbingan Terstruktur Terbatas dalam Pembelajaran Jarak Jauh untuk Meningkatkan Partisipasi Belajar Siswa SMA Negeri 2 Bayan
}

\author{
Moch. Fatkoer Rohman \\ SMA Negeri 2 Bayan, Kabupaten Lombok Utara NTB \\ Corresponding Author. Email: fatkoer@gmail.com
}

\begin{abstract}
This study aims to increase student participation through limited structured guidance in distance learning at SMA Negeri 2 Bayan. This research method used school action research with the stages of planning, action, observation and reflection which consists of 2 cycles. The instruments used were questionnaires and documentation. The data analysis technique used in this research was qualitative and quantitative descriptive analysis. The results showed that in the pre-cycle, learning participation was very low, namely only $5 \%$, (less) in the first cycle of $41 \%$ (less) and in the second cycle of $51 \%$ (sufficient). The quality of guidance in the first cycle was 74 (enough) while in the second cycle it was $84 \%$ (good). So that the results of this study can be concluded that limited structured guidance can increase student participation in SMA Negeri 2 Bayan.
\end{abstract}

\begin{abstract}
Abstrak: Penelitian ini bertujuan untuk untuk meningkatkan partisipasi belajar siswa melalui bimbingan terstruktur terbatas dalam pembelajaran jarak jauh di SMA Negeri 2 Bayan. Metode penelitan ini menggunakan penelitian tindakan sekolah dengan tahapan perencanaan, tindakan, pengamatan dan refleksi yang terdiri dari 2 siklus. Adapun instrument yang digunakan adalah angket dan dokumentasi. Teknik analisis data penelitian ini menggunakan analisis deskriptif kualitatif dan kuantitatif. Hasil penelitian menunjukkan bahwa pada pra siklus, partisipasi belajar sangat rendah yaitu hanya 5\%, (kurang) pada siklus I sebesar 41\% (kurang) dan pada siklus II sebesar 51\% (cukup). Kualitas bimbingan pada siklus I sebesar 74 (cukup) sedangkan pada siklus II sebesar $84 \%$ (baik). Sehingga hasil penelitian ini dapat disimpulkan bahwa bimbingan terstruktur terbatas dapat meningkatkan partisipasi belajar siswa SMA Negeri 2 Bayan.
\end{abstract}

How to Cite: Rohman, M. (2021). Bimbingan Terstruktur Terbatas dalam Pembelajaran Jarak Jauh untuk Meningkatkan Partisipasi Belajar Siswa SMA Negeri 2 Bayan. Jurnal Paedagogy, 8(1). doi:https://doi.org/10.33394/jp.v8i1.3283

\section{Pendahuluan}

Sejak diumumkan pemerintah mengenai kasus pertama Coronavirus Disease 2019 (Covid-19) pada bulan Maret 2020 yang lalu, Indonesia kemudian dihadapkan pada masa pandemi. Hampir seluruh sektor kehidupan terdampak, tidak terkecuali di sektor pendidikan. Covid-19 ini menular begitu cepat dan telah menyebar hampir ke semua negara, termasuk Indonesia, sehingga Badan Kesehatan Dunia (WHO) menjadikan wabah ini sebagai pandemi global pada tanggal 11 Maret 2020. Di sektor pendidikan, pemerintah melalui Kementerian Pendidikan dan Kebudayaan (Kemdikbud) telah menerapkan kebijakan learning from home atau belajar dari rumah (BDR) terutama bagi satuan pendidikan yang berada di wilayah zona kuning, oranye dan merah. Hal ini mengacu pada Keputusan Bersama Menteri Pendidikan dan Kebudayaan, Menteri Agama, Menteri Kesehatan dan Menteri Dalam Negeri tentang Panduan Penyelenggaraan Pembelajaran pada Tahun Ajaran 2020/2021 dan Tahun Akademik 2020/2021 di masa Covid-19. Bagi satuan pendidikan yang berada di zona hijau, dapat melaksanakan pembelajaran tatap muka dengan tetap memperhatikan protokol kesehatan (Asmuni \& Ahmad 2020). 
Belajar dari rumah (BDR) yang selama ini tidak pernah sama sekali dilakukan, mengakibatkan banyak guru yang gagap. Tidak tahu apa yang harus dilakukan. BDR pun banyak disalahartikan. BDR disalahartikan pemberian tugas. Ada pula yang menyalahartikan BDR itu belajar dalam jaringan atau online. Berdasarkan surat edaran Menteri Pendidikan dan Kebudayaan Republik Indonesia nomor 4 tahun 2020 ditegaskan bahwa metode pelaksanaan BDR ada 2 (dua) macam yaitu Pembelajaran jarak jauh Dalam Jaringan/online (Daring), yaitu menggunakan gawai (gadget) maupun laptop melalui beberapa portal dan aplikasi pembelajaran daring dan Pembelajaran jarak jauh Luar Jaringan/offline (Luring), menggunakan televisi, radio, modul belajar mandiri dan lembar kerja, bahan ajar cetak, alat peraga dan media belajar dari benda di lingkungan sekitar.

Pembelajaran daring pun masih banyak guru yang belum mampu menerapkan. Hal ini masih banyak guru yang belum mengenal Learning Management System (LMS). Sehingga pembelajaran daring awalnya hanya dilakuan melaui media social Whatsapp (WA) dengan hanya memberikan tugas dan siswa juga mengirim tugas melalui WA. Tanpa ada pemberian materi dan tidak ada diskusi. Pembelajaran luring juga masih belum diterapkan dengan baik. Berbagai teknik, sumber dan media yang digunakan masih belum banyak dipahami. Hal juga terjadi di SMA Negeri 2 Bayan.

Kesalahpahaman mengenai BDR di SMA Negeri 2 Bayan secara perlahan dan bertahap dibenahi. Pada awal april 2020, diselenggarakan bimtek (bimbingan teknis) tentang BDR. Dalam hal ini mengenalkan dan menggunakan LMS Google Classroom. Dalam penelitian ini dipilih Google Classroom, karena LMS ini paling sederhana, sehingga mudah digunakan. Setelah guru-guru memperoleh pemahaman tentang Google Classroom maka semua guru membuat kelas digital dan mengelola konten pembelajaran.

Terdapat kendala luar biasa yang dialami dalam pelaksanaan kelas digital. Secara garis besar ada 2 kendala yaitu dari sisi SDM (Sumber Daya Manusia) dan sarana prasarana. Dari sisi SDM adalah kekurangkesiapan guru dan siswa, sedangkan dari sisi sarana prasarana adalah infrastruktur yang belum memadai dan kurang tersedianya gawai. Dari beberapa masalah itu, difokuskan pada masalah kekurangsiapan siswa dalam pembelajaran jarak jauh. Untuk memecahkan masalah tersebut penulis mengajukan solusi berupa bimbingan terstruktur terbatas. Dengan penggunan model bimbingan ini diharapkan terjadinya peningkatan partisipasi belajar siswa SMA Negeri 2 Bayan.

Pembelajaran terjadi bila terdapat pengajar, orang yang diajar dan materi yang diajarkan. Pengajar dapat berupa guru, dosen, instruktur dan lain sebagainya. Orang yang diajar dapat berupa siswa, mahasiswa, santri dan lain sebagainya. Materi adalah sesuatu yang ditransfer dari pengajar ke orang yang diajar. Bila pengajar dan orang yang diajar dapat bertemu secara fisik maka pembelajaran disebut dengan pembelajaran tatap muka atau pembeljaran konvensional. Bila pengajar dan orang yang diajar tidak dapat bertemu secara fisik maka disebut pembelajaran jarak jauh (PJJ).

Menurut Dohmen dalam (Isdarlia, 2016) menyatakan bahwa pembelajaran jarak jauh suatu bentuk pembelajraan mandiri yang terorganisasi secara sistematis yang dilakukan oleh sekelompok tenaga pengajar yang memiliki tanggung jawab berbeda. Pembelajaran jarak jauh (pjj) dapat dilakukan dalam 2 model yaitu pembelajaran jarak jauh daring (online) dan pembelajaran jarak jauh luring (offline). PJJ daring adalah pjj yang memanfaatkan koneksi internet dalam penyelenggaraannya, sedangkan pjj luring adalah pjj yang tidak menggunakan koneksi internet dalam penyelenggaraannya.

Dalam masa pandemi Covid-19 ini, berdasarkan surat edaran Kemdikbud nomor 4 tahun 2020, kemdikbud mengambil kebijakan bahwa pembelajaran harus dilaksanakan secara 
PJJ. Dalam hal ini kemdikbud menyebutnya Belajar Dari Rumah (BDR). Kemdikbud juga membedakan BDR menjadi 2 model yaitu Pembelajaran jarak jauh Dalam Jaringan/online (Daring), yaitu menggunakan gawai (gadget) maupun laptop melalui beberapa portal dan aplikasi pembelajaran daring dan Pembelajaran jarak jauh Luar Jaringan/offline (Luring), menggunakan televisi, radio, modul belajar mandiri dan lembar kerja, bahan ajar cetak, alat peraga dan media belajar dari benda di lingkungan sekitar. Secara tegas perbedaan pembelajaran jarak jauh daring dan luring adalah pembelajaran jarak jauh daring menggunakan internet sedangkan pembelajaran jarak jauh luring tidak menggunakan internet.

PJJ daring diperlukan suatu system yang disebut dengan Learning Management System (LMS). Dengan LMS ini dibuat suatu kelas yang disebut dengan kelas digital atau kelas virtual. Pembelajarannya sering disebut dengan e-learning (pembelajaran elektronik). LMS ini ada 2 model, yaitu LMS yang kontennya sudah ada dan LMS yang kontennya masih belum ada (Rohman, 2017). LMS ini berfungsi untuk mengorganisasi konten pemebelajaran digital yang terdiri dari bahan ajar dan bahan uji. LMS yang kontennya sudah ada dan saiap pakai misalnya quipper school, sedangkan LMS yang kontennya belum ada banyak contohnya, yaitu Google Classroom, Microsoft Teams, Edmodo, Schoology dan LMS-LMS yang diinstall sendiri di hosting seperti Moodle. Untuk mendukung PJJ daring, guru dan siswa bisa memanfaatkan aplikasi-aplikasi daring sebagai sumber belajar, seperti Youtube, Wikipedia dan lain sebagainya. PJJ luring membutuhkan bahan ajar yang dirancang untuk belajar mandiri seperti modul. Modul ada 2 jenis, modul cetak dan modul elektronik (emodul). Di samping dibutuhkan pula media yang dapat mudah dipelajari seperti video. Bahan ajar berbentuk teks bisa saja digunakan namun bahan ajar seperti ini lebih sulit dipahami bila dibandingkan dalam bentuk video.

LMS yang digunakan di SMA Negeri 2 Bayan adalah Google Classroom, karena Google Classroom ini sederhana, sehingga sangat mudah digunakan. Menurut Rohman (2017) dan Daniati et al (2020), setidaknya ada 3 kelebihan Google Classroom yaitu (1) Tampilan sederhana, sehingga mudah digunakan. (2) Server google andal, sehingga situs dapat diakses dengan cepat. (3) Terintegrasi dengan semua layanan google, yaitu google forms, google drive, youtube dan lain sebagainya. Seperti halnya LMS yang lain, Google Classroom dapat digunakan untuk mengelola bahan ajar dan bahan uji, yang secara detail dapat untuk melakukan 4 hal, yaitu mengelola materi, mengelola diskusi, mengelola tugas dan penilaian. Adapun tampilan Google Classroom dapat dilihat di gambar berikut ini.

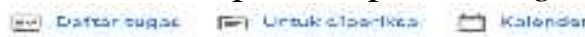

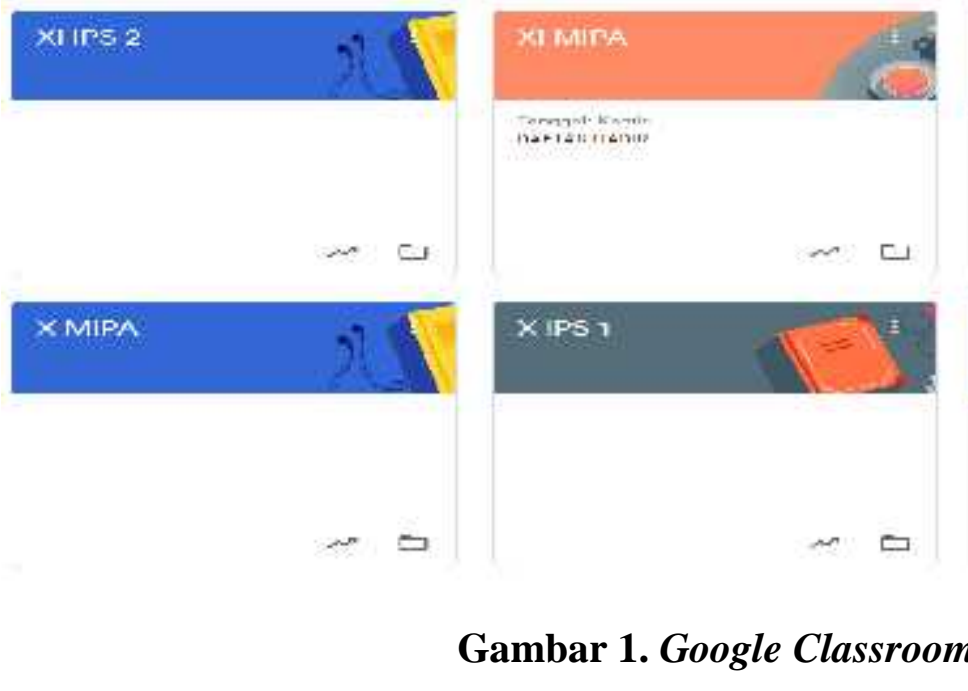

Jurnal Paedagogy Januari 2021: Vol. 8. No. 1

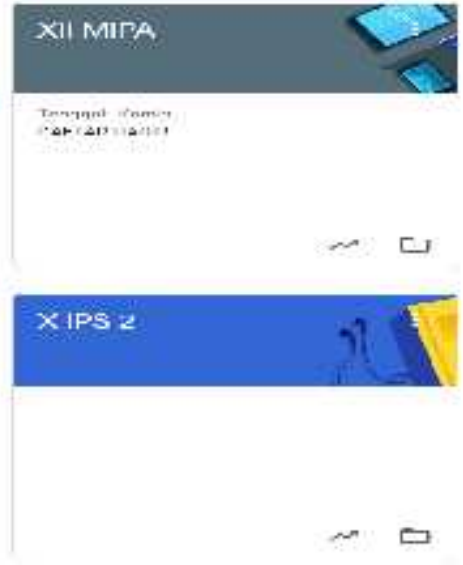


Bimbingan terstruktur terbatas adalah bimbingan oleh guru kepada semua siswa secara terjadwal dan waktunya terbatas yang hanya 60 menit per minggu. PJJ di SMA Negeri 2 Bayan dilakukan dengan 2 model yaitu PJJ daring dan PJJ luring. PJJ daring diperuntukkan bagi siswa yang mempunyai gawai (smart phone atau laptop). PJJ luring diperuntukkan bagi siswa yang tidak mempunyai HP. Berdasarkan survey diperoleh data bahwa siswa SMA Negeri 2 Bayan yang mempunyai HP hanya 50\%. SMA Negeri 2 Bayan adalah sekolah paling jauh dari kota dan sekolah paling muda di Kabupaten Lombok Utara. Kesadaran belajar paling rendah di antara semua SMA Negeri di Kabupaten Lombok Utara. Oleh karena itu, PJJ di SMA Negeri 2 Bayan banyak mengalami kendala. 2 kendala besar adalah banyak siswa yang tidak mempunyai HP dan kesadaran belajar sangat rendah. Dengan 2 kendala di atas, partisipasi belajar siswa menjadi sangat rendah. Adapun pastisipasi belajar diukur dari persetasi siswa yang mengumpulkan tugas baik melalui Google Classroom maupun dengan cara langsung menyerahkan ke sekolah. Adapun tujuan penelitian ini adalah untuk untuk meningkatkan partisipasi belajar siswa melalui bimbingan terstruktur terbatas dalam pembelajaran jarak jauh di SMA Negeri 2 Bayan.

\section{Metode Penelitian}

Metode penelitian ini menggunakan penelitian tindakan sekolah. Adapun model yang dipakai adalah model Kemmis \& Mc Taggart dimana setiap siklusnya terdiri dari 4 langkah yaitu perencanaan (plan), tindakan (act), pengamatan (observ), dan refleksi (reflect) (Kusumah \& Dwitagama, 2010).

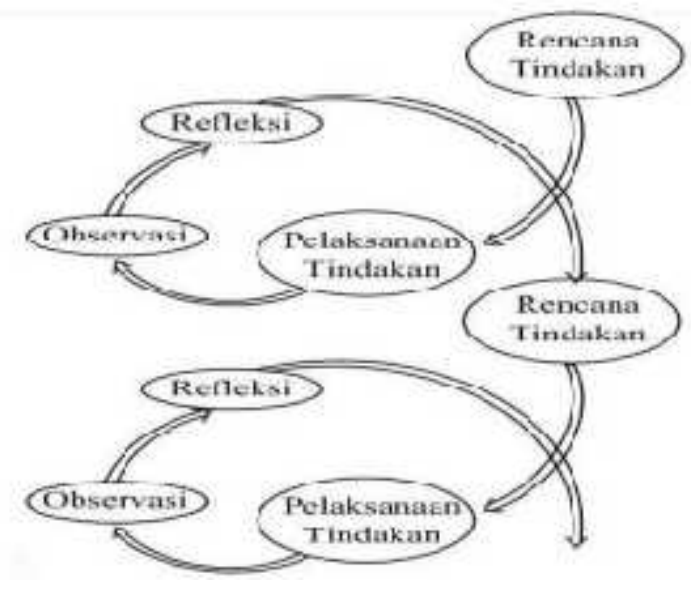

\section{Gambar 2. Siklus Penelitian Tindakan Kelas}

Teknik pengumpulan penelitian ini menggunakan angket dan dokumentasi. Angket terhadap guru untuk menggali pelaksaan bimbingan apakah sudah sesuai dengan petunjuk. Sedangkan dokumentasi adalah untuk mengetahui angka keaktivan siswa dalam mengumpulkan tugas. Bentuk instrumen adalah daftar pertanyaan wawancara dan format rekapitulasi keaktifan mengumpulkan tugas. Teknik analisis data penelitian ini menggunakan analisis deskriptif kualitatif dan kuantitatif. Keterlaksanaan bimbingan dihitung dengan rumus sebagai berikut.

$N=\frac{S}{S \text { jhaks }} \times 100$

$N=$ Nilai Pelaksanaan Bimbingan

$\mathrm{s}=$ Skor Pelaksanaan Bimbingan 
S Maks = Skor Maksimum Pembelajaran

Kategori Nilai Pelaksanaan Bimbingan adalah sebagai berikut.

$\begin{array}{ll}N \leq 50 \% & : \text { Kurang } \\ 50 \%<N \leq 75 \% & \text { : Cukup } \\ 75 \%<N \leq 90 \% & \text { : Baik } \\ 90 \%<N \leq 100 \% & \text { :Sangat Baik }\end{array}$

Partisipasi belajar dihitung dengan rumus;

$P=\frac{n}{S}$

$\mathrm{P}=$ Persentasi siswa yang mengumpulan tugas

$\mathrm{n}=$ Jumlah siswa yang mengumpulkan tugas

$\mathrm{S}=$ Jumlah siswa

Kategori partisipasi belajar adalah sebagai berikut.

$\mathrm{P} \leq 50 \quad$ : Kurang

$50<\mu \leq 75$ : Cukup

$75<\mu \leq 90:$ Baik

$90<\beta \leq 100$ : Sangat Baik

Adapun indikator keberhasilan penelitian ini adalah; (1) Bimbingan terstruktur terbatas dikatakan berhasil bila nilainya minimal 76 (Baik); dan (2) Partipasi belajar dikatakan berhasil bila nilainya minimal $51 \%$ (cukup).

\section{Hasil Penelitian dan Pembahasan Deskripsi Pra Siklus}

Penelitian ini mengamati pembelajaran jarak jauh di awal-awal pandemi Covid-19. Pengamatan ini berlangsung dari Maret sampai dengan Juni 2020, kurang lebih selama 4 bulan. Guru dan siswa masih adaptasi melaksanakan pembelajaran jarak jauh. Guru-guru mulai dilatih menggunakan Google Classroom untuk pembelajaran daring. Mencari bahan ajar digital di internet. Sementar siswa banyak yang tidak memiliki HP. Yang memiliki HP sekitar 50\%. Itu pun nomor HP belum semua disimpan oleh pihak sekolah dan belum semua masuk di grup Whatsapp. Terdapat 2 kendala besar yang menghambat pelaksanaan PJJ yaitu masalah SDM dan sarana prasarana. SDM dari sisi guru, belum terbiasa dengan PJJ sedang dari sisi siswa, selain belum terbiasa PJJ juga banyak siswa yang tidak memiliki HP. Yang masuk di kelas digital Google Classroom rata-rata hanya 8\%. Sementara PJJ luring belum dilaksanakan. Akibatnya partisipasi belajar sangat rendah. Partisipasi belajar 5\%.

\section{Deskripsi Siklus I}

Untuk memecahkan partisipasi beljar yang rendah, pada siklus pertama, penulis melakukan tindakan yang penulis sebut bimbingan terbatas. Siklus pertama ini berlangsung sekitar 1 bulan dan setiap 2 minggu dievaluasi. Bimbingan terbatas adalah bimbingan terjadwal yang jamnya terbatas. Pada siklus pertama ini hanya 60 menit per minggu. Adapun materi yang disampaikan dalam bimbingan adalah bimbingan penggunaan Google Classroom dan bimbingan materi. Kualitas bimbingan ini penulis nilai dengan teknik angket. Hasil penilaiannya adalah 74. Belum mencapai hasil baik. Untuk partisipasi belajar juga sangat rendah. Berdasarkan rekapitulasi wakil kurikulum hasilnya adalah sebagai berikut: (1) Partisipasi daring (Melalui Google Classroom) 6\% dan (2) Partisipasi luring 35\%. Jadi total partisipasi hanya $41 \%$ dengan kategori kurang. 


\section{Deskripsi Siklus II}

Setelah tindakan pada siklus I dilakukan, selanjutnya dilakukan refleksi untuk menggali kekurangan-keurangan pada siklus I. Adapun kelemahan-kelemahan itu adalah masih ada beberapa guru (40\%) yang kurang menguasai Google Classroom. Selain itu alokasi waktu yang hanya 60 menit per minggu masih dirasa kurang cukup. Dari 2 kelemahan ini penulis perbaiki. Kelemahan pertama, penulis lakukan bimbingan teknis lagi terhadap guru-guru dalam penguasaan Google Classroom, sedangkan kelemahan kedua penulis atasi dengan menambah jam bimbingan, menjadi 120 menit yang semula 60 menit. Setelah mengisi angket, didapat kualitas bimbingan meningkat menjadi 84\%, katageri baik. Sedangkan partisipasi belajar juga meningkat menjadi 51\%. Dengan demikian dapat dibandingkan dari pra siklus, siklus I dan Siklus II sebagai berikut.

Tabel 1. Hasil Penelitian

\begin{tabular}{|l|l|l|l|}
\hline \multicolumn{1}{|c|}{ Item } & \multicolumn{1}{|c|}{ Pra Siklus } & \multicolumn{1}{c|}{ Siklus I } & \multicolumn{1}{c|}{ Siklus II } \\
\hline $\begin{array}{l}\text { Bimbingan } \\
\text { Terstruktur } \\
\text { Terbatas }\end{array}$ & $\begin{array}{l}\text { Belum } \\
\text { dilakukan }\end{array}$ & 74 & 84 \\
\hline $\begin{array}{l}\text { Partisipasi } \\
\text { Belajar }\end{array}$ & $5 \%$ & $41 \%$ & $51 \%$ \\
\hline
\end{tabular}

\section{Kesimpulan}

Kesimpulan yang diperoleh dari hasil penelitian ini adalah bimbingan terstruktur terbatas dapat meningkatkan partisipasi belajar siswa SMA Negeri 2 Bayan. Hal ini dibuktikan berdasarkan data pra siklus, partisipasi belajar sangat rendah yaitu hanya 5\%, (kurang) pada siklus I sebesar 41\% (kurang) dan pada siklus II sebesar 51\% (cukup). Kualitas bimbingan pada siklus I sebesar 74 (cukup) sedangkan pada siklus II sebesar 84\% (baik).

\section{Saran}

Adapun saran yang dapat disampaikan berdasarkan hasil penelitian ini adalah; (1) Guru sudah harus menguasai teknonolgi terutama LMS (Learning Management System) untuk pembelajaran. Ada pun pemilihan LMS disesuaikan dengan kondisi dan kebutuhan. (2) Guru harus mengembangkan media dan sumber belajar baik elektronik maupun cetak.

\section{Daftar Pustaka}

Ahmad, A. (2020). Peningkatan Kompetensi Pedagogik Guru dalam Pembelajaran Jarak Jauh Melalui Pendampingan Sistem Daring, Luring, atau Kombinasi pada Masa New Normal Covid-19. Jurnal Paedagogy, $\quad 7(4), \quad 258-264$. doi:https://doi.org/10.33394/jp.v7i4.2803

Asmuni, A. (2020). Problematika Pembelajaran Daring di Masa Pandemi Covid-19 dan Solusi Pemecahannya. Jurnal Paedagogy, 7(4), 281-288. doi:https://doi.org/10.33394/jp.v7i4.2941

Bahasa, B. P. (n.d.). KBBI Daring. diambil 14 November, 2020, dari KBBI Daring: https://kbbi.kemdikbud.go.id/

Bera, L. (2018). Peningkatan Partisipasi Belajar Mata Pelajaran IPS Melalui Strategi Pembelajaran Word Square pada Siswa Kelas VA SD Inpres Iligetang. Jurnal Kependidikan: Jurnal Hasil Penelitian dan Kajian Kepustakaan di Bidang 
Pendidikan, Pengajaran dan Pembelajaran, 4(2), 163-172. doi: HYPERLINK "https://doi.org/10.33394/jk.v4i2.1125" https://doi.org/10.33394/jk.v4i2.1125

Daniati, D., Ismanto, B., \& Luhsasi, D. (2020). Upaya Peningkatan Motivasi dan Hasil Belajar Mahasiswa dengan Penerapan Model Pembelajaran E-Learning Berbasis Google Classroom pada Masa Pandemi Covid-19. Jurnal Kependidikan: Jurnal Hasil Penelitian dan Kajian Kepustakaan di Bidang Pendidikan, Pengajaran dan Pembelajaran, 6(3), 601-608. doi: HYPERLINK "https://doi.org/10.33394/jk.v6i3.2642" https://doi.org/10.33394/jk.v6i3.2642

Isdarlia, S. (2016). Pembelajaran Jarak Jauh. Kendari: IAIN Kendari.

Kusumah, W. (2010). Mengenal Penelitian Tindakan Kelas. Jakarta: Indeks.

Muzakkir, M., Wibawa, R., Astutik, F., \& Muhakkikin, M. (2018). Pengembangan Perangkat Model Blended Learning untuk Meningkatkan Efektivitas Penerapan Pendidikan Jarak Jauh di SMKN 2 Gerung. Jurnal Kependidikan: Jurnal Hasil Penelitian dan Kajian Kepustakaan di Bidang Pendidikan, Pengajaran dan Pembelajaran, 4(2), 173177. doi: HYPERLINK "https://doi.org/10.33394/jk.v4i2.1126" https://doi.org/10.33394/jk.v4i2.1126

Rohman, M. F. (2017). Google Classroom: Jadikan Kelas Digital di Genggaman Anda. Bojonegoro: Pustaka Intermedia. 